\title{
Determinants of share-based compensation plans in Central and Eastern European public companies: An institutional analysis*
}

\author{
Marion Festing, Ihar Sahakiants**
}

This paper discusses the adoption of share-based compensation plans among Central and Eastern European (CEE) public companies composing major national stock exchange indices in Poland (WIG 20), the Czech Republic (PX) and Hungary (BUX). The analysis shows that the spread of such pay practices depends on the characteristics of major shareholders of the company, the state and foreign parent companies being the most prominent influencing factors. The results are discussed in the light of the legal environment in respective countries.

Im Zentrum des vorliegenden Artikels stehen aktienbasierte Vergütungspläne in mittel- und osteuropäischen (MOE) Aktiengesellschaften, die in den nationalen Leitindizes in Polen (WIG 20), der Tschechischen Republik (PX) und Ungarn (BUX) vertreten sind. Die Analyse zeigt, dass die Verbreitung dieser Praktiken wesentlich von den Charakteristika der Hauptaktionäre der Unternehmen abhängt. Hier stellen der Staat und die ausländischen Unternehmen die wichtigsten Einflussfaktoren dar. Die Ergebnisse der Studie werden vor dem Hintergrund des regulativen Kontextes in den jeweiligen Ländern diskutiert.

Keywords: Central and Eastern Europe, CEO Compensation, Comparative HRM, Institutional Environment, Ownership/Control Structures.

* Manuscript received: 31.05.2011, accepted 22.09.2011 (1 revision)

** Marion Festing, Prof. Dr., ESCP Europe Berlin. Main research areas: International human resource management, global leadership, strategic human resource management, globalisation processes, global compensation, global careers. Corresponding address: marion.festing@escpeurope.de

Ihar Sahakiants, research assistant, ESCP Europe Berlin. Main research areas: International and comparative compensation, adoption and path dependence of organisational practices, labour relations. 


\section{Introduction}

Although the first example of research on executive compensation dates back to the 1930s, the topic of directors' pay has increasingly been the focus of theoretical research and normative discussions over the last two decades (Florin et al. 2010). The last three years, dominated by the financial crisis, have revealed the drawbacks of existing remuneration systems and fuelled further discussions. Not only is the adequacy of directors' pay now being discussed, but also executive compensation structures, which allegedly stimulate excessive risk-taking, have been blamed for triggering the financial crisis (for a summary of drawbacks of performance-related executive compensation cf. Bebchuk 2010). However, while the literature on executive compensation in the USA and other industrialised countries is rather extensive, there is a lack of information on executive compensation in companies within the CEE region. This is not only true for the practitioner literature or mass media, but also for academic research. While a rather large literature body has been devoted to the "Americanisation" of executive pay in industrialised countries such as Germany (Chizema/Buck 2006; Kurdelbusch 2002), research on directors' pay in CEE is scarce.

In this paper, we focus our analysis on the determinants of the dissemination of "American-type" pay practices - in particular, share-based payments as their most prominent example - in CEE countries such as the Czech Republic, Hungary and Poland. The rationale behind the selection of these three countries is the need to find economies that would be comparable with each other, on the one hand, and represent the whole region, on the other hand. Indeed, the Czech Republic, Hungary and Poland were the largest CEE economies to join the European Union in 2004 and are members of the Visegrád Four Group that have not introduced the Euro. Most importantly, however, these three countries host major stock exchanges in the CEE region (Köke/Schröder 2003), which is, in our opinion, of primary importance for the analysis of share-based compensation.

To this end, we study the spread of share-based payments in local public companies, represented on the major stock exchange indices in the above countries, in the light of several impact factors such as ownership structures and industry sectors. The results of the study are discussed based on the analysis of the institutional - above all, regulatory - environments in the respective countries. Taking this approach, this paper is designed to contribute to the knowledge about executive compensation in CEE companies, by considering the specific context of this region and analysing the influence of ownership structures and industry characteristics on the implementation of share-based compensation plans.

The remainder of the paper is structured as follows. First, we present the theoretical background of the study, following which we describe the regulatory 
environment as the major determinant of executive compensation practices in our chosen countries. The empirical part is introduced by a description of the methodology, which is followed by the results and a discussion. In the conclusion, we outline implications for further research and practice.

\section{Theoretical Background}

\section{Dominant explanations of executive compensation}

While there are several theories that explain executive pay in general (e.g. expectancy theory, efficiency pay), the spread of mid- and long-term incentive schemes, including share-based plans, is traditionally discussed from the agency theory perspective (Pennings 1993). In fact, this theory seems to explain organisational practices in public corporations the best by analysing the relationships between shareholders as principals (also represented on supervisory boards in two-tier board systems) and executive directors as agents. Two major problems arising from principal-agent relationships are (1) agency problems stemming from goal conflicts or information asymmetry between the principal and agent and (2) the problem of risk-sharing (for a comprehensive overview and assessment of agency theory cf. Eisenhardt 1989). To eliminate or reduce these problems, shareholders have put forward various compensation plans to their managers, including stock option schemes (Jensen/Meckling 1976).

However, there have been numerous discussions on the cross-cultural application of organisation theories, including agency theory. Adherents to the culture-bound assumption argue with advocates of the culture-free point of view (Budhwar/Sparrow 2002) on the possibilities and limitations of transferring organisational practices across cultures (for a discussion of particularist ["emic"] and universalist ["etic"] points of view cf. Von Glinow et al. 2002). Very often, culture-bound arguments are based on the study of Hofstede (1980), which proposes that nations differ across such cultural dimensions as individualism vs. collectivism, masculinity vs. femininity, power distance and uncertainty avoidance. As a result, inter alia relying on several of the above dimensions, Sharp and Salter suggest that "agency theory may lack cross-cultural validity" (1997:117).

Nevertheless, executive pay in particular - and agency relationships in public corporations in general - is more often discussed from the institutional point of view, stressing the historically embedded differences in institutional arrangements among different countries (Chizema/Buck 2006). For instance, Lan and Heracleous propose a redefined agency theory based on the analysis of legal systems, which "may be seen as more applicable and palatable to countries other than those in the Anglo-Saxon world" (2010:310). 


\section{Explaining the transfer of share-based compensation plans}

Since we aim in this paper to study the determinants of share-based compensation practices as an example of a transfer of American-type organisation practices in the CEE region, our research is based on theoretical approaches explaining the transfer and adoption of organisational practices. The literature on the transfer of organisational practices is dominated by the institutional explanations for this process (cf. Kostova/Roth 2002). In contrast to rational choice arguments (Abrahamson 1991), the importance of the isomorphic process is underscored. According to DiMaggio and Powell (1991), three mechanisms enable the isomorphism of organisational practices, namely normative, mimetic and coercive isomorphism. With respect to compensation practices, the mimetic mechanism is often the focus of analysis, whereby companies seek to avoid uncertainty by "mimicking" the pay practices of successful companies. Conversely, emerging legislation on the adequacy of executive compensation adopted by a number of industrialised states is an example of coercive isomorphism.

That said, apart from coercive isomorphism, it is often very difficult to attribute empirically observed factors influencing the transfer of organisational practices to any of the isomorphic forces described above. One example is the transfer of US-American disclosure standards to other countries, the impact of which can be attributed to several isomorphic mechanisms. While disclosure standards could be a source of coercive (in the case of a mandatory disclosure) or normative isomorphism (if disclosure practices are observed in accordance with recommendations of the local Codes of Corporate Governance, having a "comply or explain" nature), the resulting dissemination of American-type compensation practices can rather be attributed to mimetic (the wish of shareholders to minimise risks in uncertain situations) and normative (promoting share-based compensation as an attribute of executive compensation) mechanisms.

In their work on compensation practices in CEE, Festing and Sahakiants (2010) argued that there is a need for a separate study of the application of isomorphism theory in transformation CEE economies characterised by relatively unstable environments. While the breakdown of state socialist systems can certainly be regarded as a significant exogenous shock that theoretically breaks the historical path of the countries (Deeg 2005), the level of embeddedness in the pathdependent organisational practices of companies belonging to different segments of post-socialist economies (cf. Martin 2008) and featuring different ownership types needs to be especially considered. It was further argued that the analysis of compensatory practices should initially be conducted in view of the impact of the regulatory environment and the influence of trade unions, multinational corporations, labour market contexts, path-dependent factors determined by founding history and ownership structures of the companies. However, with 
respect to the public corporations studied in this paper, we believe that several impact factors could be excluded from the analysis. Firstly, given that sharebased compensation plans are more often provided to top management employees, the impact of trade unions could be considered less significant. Secondly, as all the countries studied opened their stock markets only after 1990, publicly-traded companies did not exist in their present form during the state-socialist period, so it is difficult to make any conclusions on the impact of path dependency resulting from the historical development of a company (e.g. its practices as a fully state-owned company prior to privatisation or initial public offering [IPO]). And thirdly, given the global or at least regional (CEE) character and mobility of executive labour markets, the specific conditions of general local labour markets with indicators such as employment rate, mobility, etc. are expected to have little influence on directors' compensation design.

Thus, in our paper we will focus on ownership structures and industry traits as the major expected determinants of share-based compensation practices within the countries' specific regulatory environments.

\section{Regulatory Environment}

According to Carroll and Ciscel (1982), the legal environment has a major impact on executive compensation. This is true both for laws pertaining to the industry in which a company operates and regulations directly related to compensation issues.

\section{Direct Regulation}

The regulation of compensation has quite a substantial history, not only in centrally planned economies, but also in the Western industrialised world. While the most prominent example of a long tradition of direct executive compensation regulation can be found in India (Cheffins/Thomas 2002), even in the United States there have been several attempts since the 1930s to curb executive pay (Jackson 2011). In their communiqué in Pittsburgh, G20 member countries stated the need to rethink current executive compensation practices, which encourage excessive risk-taking, and to put limits on bonuses. However, the effectiveness and long-term enforceability of such measures are questionable (Richardson 2009).

In the CEE region there are several examples of laws setting limits on executive rewards. Out of the three countries analysed in the present study, Poland is the only one that implements direct regulations with respect to executive pay. The so-called "Salary Cap Act" (Act on Remuneration of Persons Managing Certain Legal Entities, dated March 3, 2000) limits the remuneration of company directors, where the state treasury holds more than $50 \%$ of shares. According to the Act, the maximum monthly salary of management board members (the executive organ within the Polish two-tier board system) is limited to six times 
the average wage in the respective industry. Total remuneration may consist of a monthly salary, annual awards, fringe benefits and severance pay. The amount of payment other than monthly salary and benefits is also limited to amounts calculated on the basis of the average wage. The current government introduced a bill in 2008 to remove the "Salary Cap Act", which was vetoed by the then acting and now late President Lech Kaczynski (Bertelsmann Stiftung 2010). Neither Hungary nor the Czech Republic has any direct regulation in relation to executive pay.

\section{Disclosure Requirements}

Intuitively, it could be supposed that the disclosure of an executive's remuneration would hardly be associated with the adoption of compensation practices. However, according to Cheffins and Thomas, "the approach countries take towards the disclosure of executive pay will likely dictate to some degree the extent to which the sort of performance-oriented compensation packages that are prevalent in the US become popular elsewhere" (2002:18). According to Park et al. (2001), the mandated individual director's remuneration disclosure requirements in Canada have led to increasing total pay and market-based incentives for executives. Moreover, Craighead et al. (2004) found an effect of mandatory disclosure on CEO performance-related compensation, including stock options plans. This effect varies depending on whether the company is widely or closely held, or the compensation type (cash or share-based).

The mandated disclosure of executive compensation dates back to 1934 in the United States (Craighead et al. 2004). Until now, the United States has probably had the strictest disclosure regime in the world. The Securities and Exchange Commission (SEC) requires public companies to disclose compensation policies and details for top executive officers. In 2006 and 2009, respectively, two significant amendments were made with respect to stock options and inter alia the provision of information on remuneration policies for non-executive employees, as well as fees paid to compensation consultants (Chung 2009). According to Craighead et al. (2004), SEC regulations inspired a number of countries, including France, Japan and Canada, to adopt similar disclosure regulations.

In the European Union, the disclosure of directors' remuneration was fostered by the European Commission by adopting the Recommendation of 14 December 2004 (2004/913/EC). According to the special Report of the European Commission on the application by EU Member States of the above recommendation, about two-thirds of the member states have enforced regulations in this matter (European Commission 2007). However, according to Mercer (2007), there are large variations in these disclosure practices - even in Western Europe. 
Again, out of the CEE countries studied, Poland has the strictest mandatory disclosure rules. Since 2005, Polish companies have been required to disclose the remuneration of individual directors. In the Czech Republic, mandatory disclosure regulations were adopted in 2004; however, they are rather limited in scope and require information on the total income of all members of the boards of directors, supervisory boards and other key executives. In Hungary, there are no mandatory requirements on the disclosure of director's remuneration; rather, the Corporate Governance Recommendations published by the Budapest Stock Exchange in 2008 only recommend that companies disclose this information.

Hence, as in the case of direct pay regulation, Poland has the strictest laws on the disclosure of executive remuneration, which could have an indirect effect on the level and structure of directors' pay.

Thus, based on the findings of Carroll and Ciscel (1982) on the importance of overall legal environments, we assume that mandated disclosure requirements will also affect compensation designs, as well as direct regulations such as the Polish "Salary Cap Act".

\section{Methodology}

The analysis of share-based compensation practices is based on descriptions of equity-based payments in the annual reports and financial statements for 2009 of local companies represented in the major indices of the Warsaw (WIG 20), Prague (PX) and Budapest (BUX) stock exchanges - as of December 2, 2010.

In view of a reported generally low response rate to surveys conducted in CEE countries (Koubek 2009), the qualitative design of the study based on the content analysis of annual reports seems very advantageous. For instance, the number of Hungarian and Czech companies that participated in the CRANET survey in 2004-2005 was very low compared to all participating industrialised countries, while no survey was conducted in Poland (Karoliny et al. 2009). Moreover, an important advantage of this method compared to large-scale surveys is that it allows us to study companies comparable in size and legal form.

The initial sample included 46 companies composing WIG 20, PX and BUX indices. Only 32 companies, however, could be analysed (see Table 1 below)

In the first instance, for two reasons we excluded organisations incorporated in countries other than the base country of the respective stock exchange. First of all, the focus of operations and the majority of revenues of some of the foreign companies composing the above indices were outside the respective CEE country. An example of such a company is Erste Group Bank AG, a Viennabased corporation listed on the Prague Stock Exchange. Therefore, unlike, for instance, Philip Morris ČR a.s., a subsidiary of Philip Morris Corporation in the 
Czech Republic, the annual report of the Erste Group Bank AG describes all financial and organisational practices at the Austrian parent company.

Table 1. Composition of WIG 20, PX and BUX indices (as of 2 Dec, 2010)

\begin{tabular}{lcccccc}
\hline Index & Country & $\begin{array}{l}\text { Number of } \\
\text { companies }\end{array}$ & $\begin{array}{l}\text { Head } \\
\text { offices of } \\
\text { the } \\
\text { companies }\end{array}$ & $\begin{array}{l}\text { Number of } \\
\text { companies } \\
\text { with local } \\
\text { HQ }\end{array}$ & $\begin{array}{l}\text { Companies with no } \\
\text { English language } \\
\text { reports } \\
\text { remuneration } \\
\text { reports available }\end{array}$ & $\begin{array}{l}\text { Number of } \\
\text { companies } \\
\text { analysed }\end{array}$ \\
\hline WIG20 & $\begin{array}{l}\text { Poland } \\
\text { Czech } \\
\text { Republic }\end{array}$ & 20 & $\begin{array}{l}\text { PL, CZ } \\
\text { CZ, BM, } \\
\text { NL, LU, } \\
\text { AT, US }\end{array}$ & 5 & 1 & 18 \\
\\
BUX
\end{tabular}

Source: Company Reports

Secondly, the organisational practices of foreign companies such as Amsterdambased New World Resources N.V., with the majority of its production volumes and sales generated in CEE countries, might additionally be influenced by institutional factors in their home countries. Moreover, the Czech utilities company ČEZ a.s., represented both in the WIG 20 and PX indices, was included in the analysis just once. Thus, 11 foreign companies were excluded from the analysis, including one company from WIG 20 (ČEZ a. s.), nine from $\mathrm{PX}$ and one from the BUX stock index.

Moreover, not all of the companies provided information on executive remuneration, or reports in English. Thus, we excluded one such company represented in the WIG 20 index (no information on compensation practices) and two belonging to the BUX index (no information on compensation practices in the one case and no English language report in the other)

We collected information not only on the existence of share-based compensation plans in 2009, but also generally on the implementation of such schemes within the last ten years. This was motivated by the fact that it was expected that a number of companies could have stopped their equity-based remuneration plans during the crisis, ostensibly due to hypothetically lower sales volumes. We believe that collecting information on the implementation of such remuneration schemes within a certain period of time, without concentrating on a specific financial year, is feasible due to the following two reasons. First of all, in this study we aim at identifying the transfer mechanisms of organisational practices, irrespective of the implementation timeline. Secondly, we focus on ownership structures and not on changing the personal characteristics of decision-makers 
(e.g. the structure of remuneration committees), which might influence specific decisions on pay design at a certain point in time. By doing this, we include in our analysis share-based compensation schemes implemented by companies prior to 2009, but only if there were no significant changes in the ownership structure of a particular company compared to the financial year 2009.

The study is qualitative and explorative in its nature and is aimed at analysing the impact of ownership structures and industry traits on the adoption of American-type compensation practices, such as share-based compensation plans, in CEE countries. To this end, we specifically focused on ownership structures by identifying the largest (compared to other shareholders, irrespective of shares held) and majority (owning over 50\% of company stock) shareholders, as well as industry affiliation.

\section{Results}

The analysis showed that the majority (about 66\%) of companies studied implemented some type of share-based compensation plan. The results are presented in Table 2.

The following four major types of share-based plans were identified.

Stock option plans (SOP). This category encompasses all plans similar to stock option schemes, irrespective of whether they actually granted convertible bonds or warrants with a right to acquire shares. In fact, convertible bond schemes were typical to German corporations (cf. Cheffins/Thomas 2002:16) prior to adopting the Corporate Sector Supervisory and Transparency Law (KonTraG) in 1998 (Pendleton et al. 2002).

Stock appreciation rights (SAR) are cash incentives based on the company's share price, with conditions similar to SOP.

Stock bonus plans (SBP) include all arrangements where company shares are granted as a part of the incentive package.

Employee share purchase plans (ESPP) are share-based incentive schemes that allow a company's employees to acquire company shares on preferential terms.

Less widespread were share-based schemes such as phantom stock, cash-based mid-term incentives and performance share plans.

Additionally, information about the shareholder structure of the companies is presented in Table 2 by identifying the largest shareholders, private persons as shareholders of the company and subsidiaries (identified in Table 2 by the word "parent" in brackets). In this paper we define subsidiaries as companies that are members of a group of companies, and which describe their main shareholder as the parent company in their periodic reports. For instance, BRE Bank S.A., which is itself the parent company in the BRE Bank S.A. Group, describes 
Commerzbank Auslandsbanken Holding AG, which held $69.78 \%$ of ordinary bank shares as of 31 December 2009, as the parent company in the related parties section of its annual report for 2009. In almost all cases, the parent companies are majority shareholders with over $50 \%$ of shares. The only exception is France Telekom, which as of December 31, 2009 owned 49.79\% of its Polish subsidiary Telekomunikacja Polska S.A.

Table 3 shows the distribution of companies by shareholder structure and the spread of share-based compensation plans.

The figures presented in Table 3 show that, at least in Poland, share ownership by the state is a good predictor of the existence of share-based compensation plans - none of the six companies represented in the WIG 20 stock exchange index has implemented such schemes. Interestingly, only three of them are controlled by the state and thus fall under the "Salary Cap Act". In the Czech Republic this impact obviously does not exist. Although only one state-owned Czech company was analysed, it could still be considered proof that being a state-controlled company in the Czech Republic does not automatically mean any constraints on the transfer of modern pay practices. Indeed, out of the eight CEE companies co-owned or controlled by the state in this study, the Czech company (ČEZ, a.s.) had one of the greatest shares of its equity capital owned by the state (about 70\%). In Hungary, although the only company with the state as a major shareholder did not implement any share-based compensation plans, it is not possible to make any definite statement on the impact of state ownership based solely on one case.

In addition to the impact of state ownership on the pay practices of public companies in Poland, a major impact of foreign investors, notably the foreignbased parent companies of the CEE firms studied, could be identified. In the majority of cases (15 companies), the largest amounts of company shares were held by foreign investors. Out of 11 subsidiaries, ten were subsidiaries of foreign-based parent companies, while one was a subsidiary of a local parent company (Tiszai Vegyi Kombinát Nyrt. is a local subsidiary of the Hungarian oil and gas company MOL). The majority of parent companies (seven out of 11) transferred their own share-based compensation plans to their CEE subsidiaries.

Three major share-based compensation transfer mechanisms were identified: (1) opening parent company schemes for the participation of employees in CEE subsidiaries (e.g. offering CEE employees the chance to buy parent company stocks at preferential terms); (2) copying of parent company compensation plans in their CEE subsidiaries and (3) the transfer of modified parent company compensation plans. 
Table 2. Spread of share-based Compensation Plans in WIG 20, PX and BUX companies

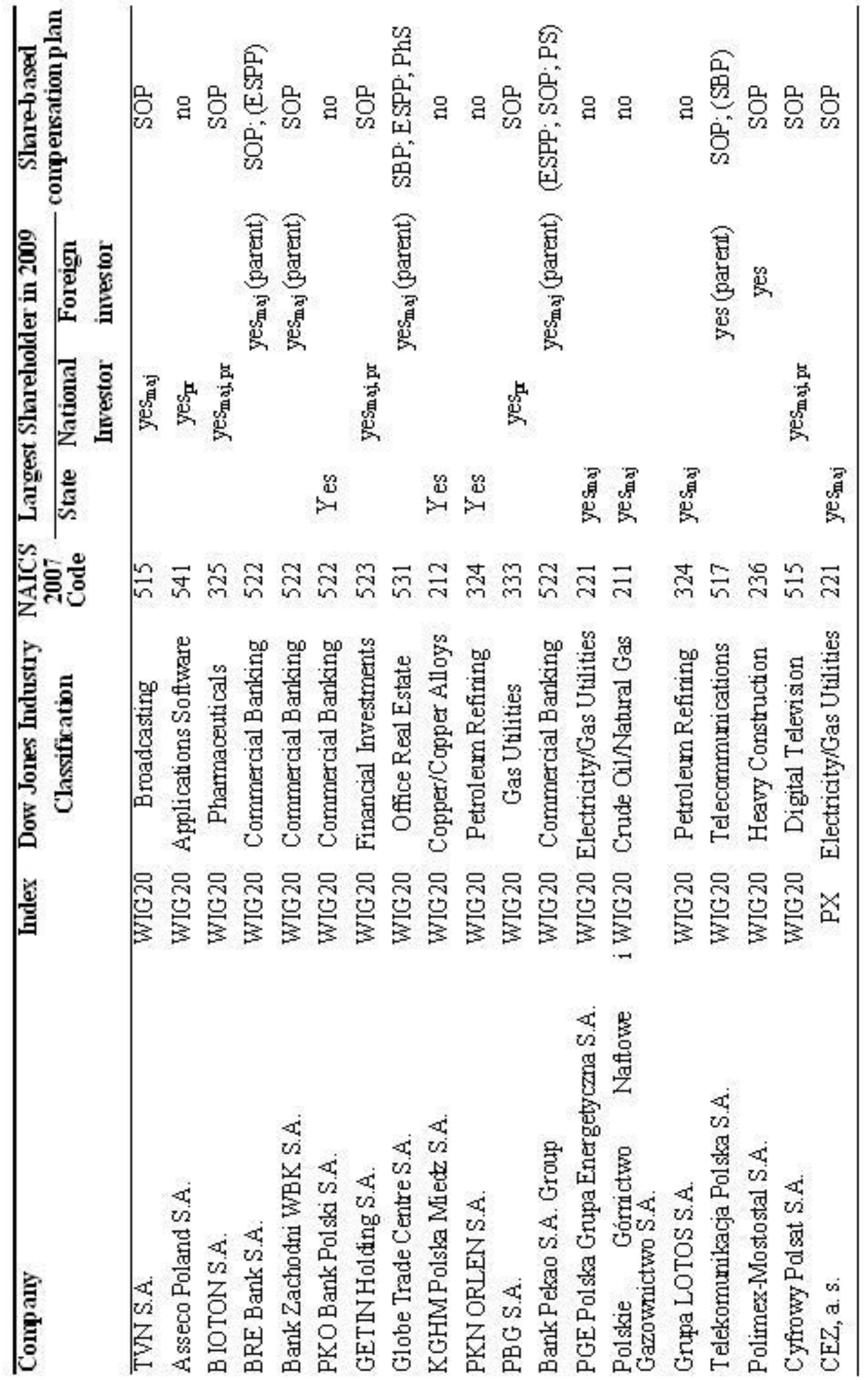


Table 2. Continued

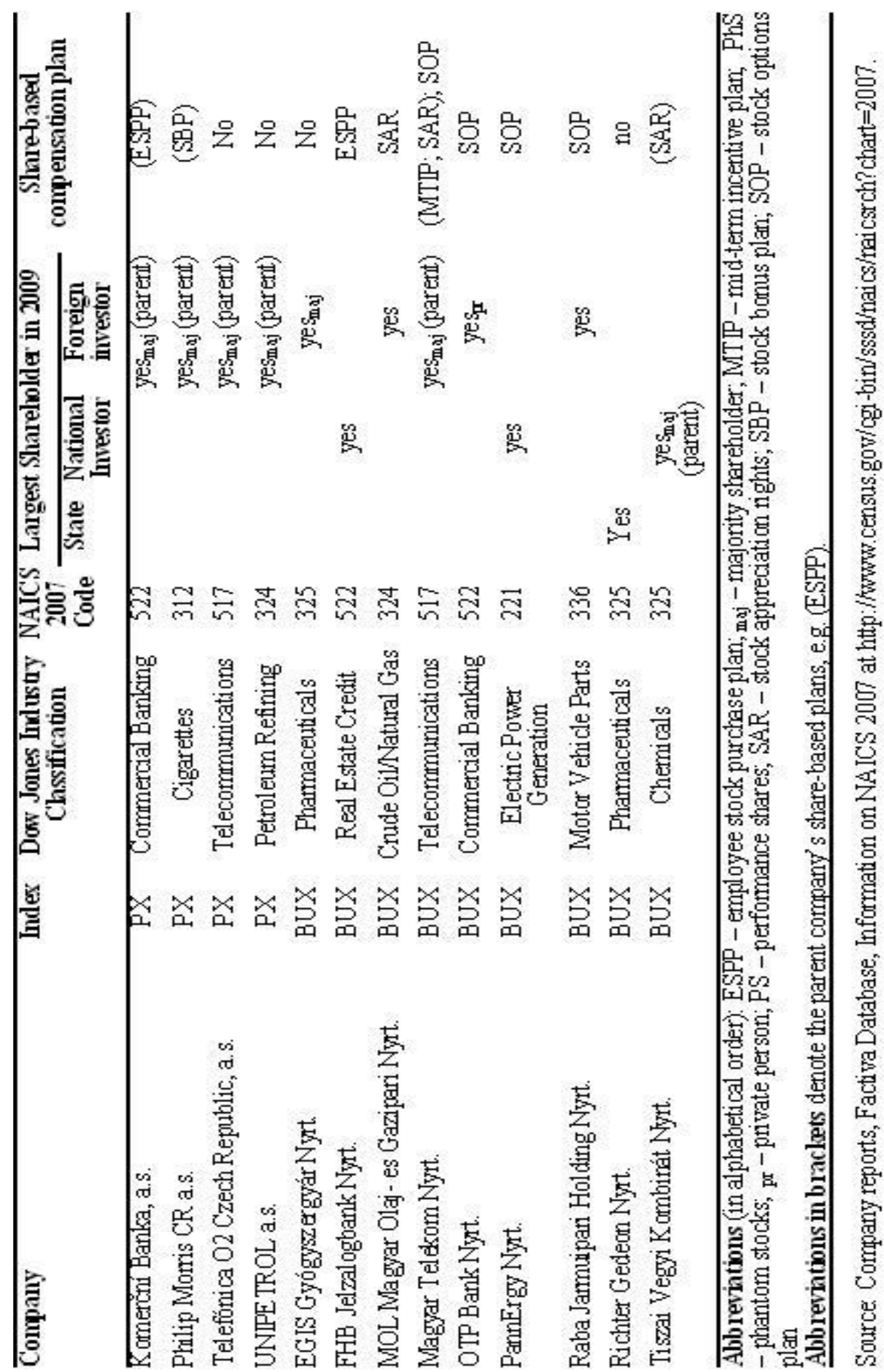


Table 3. Shareholder Structure and Share-based Compensation Plans in WIG 20, PX and BUX companies

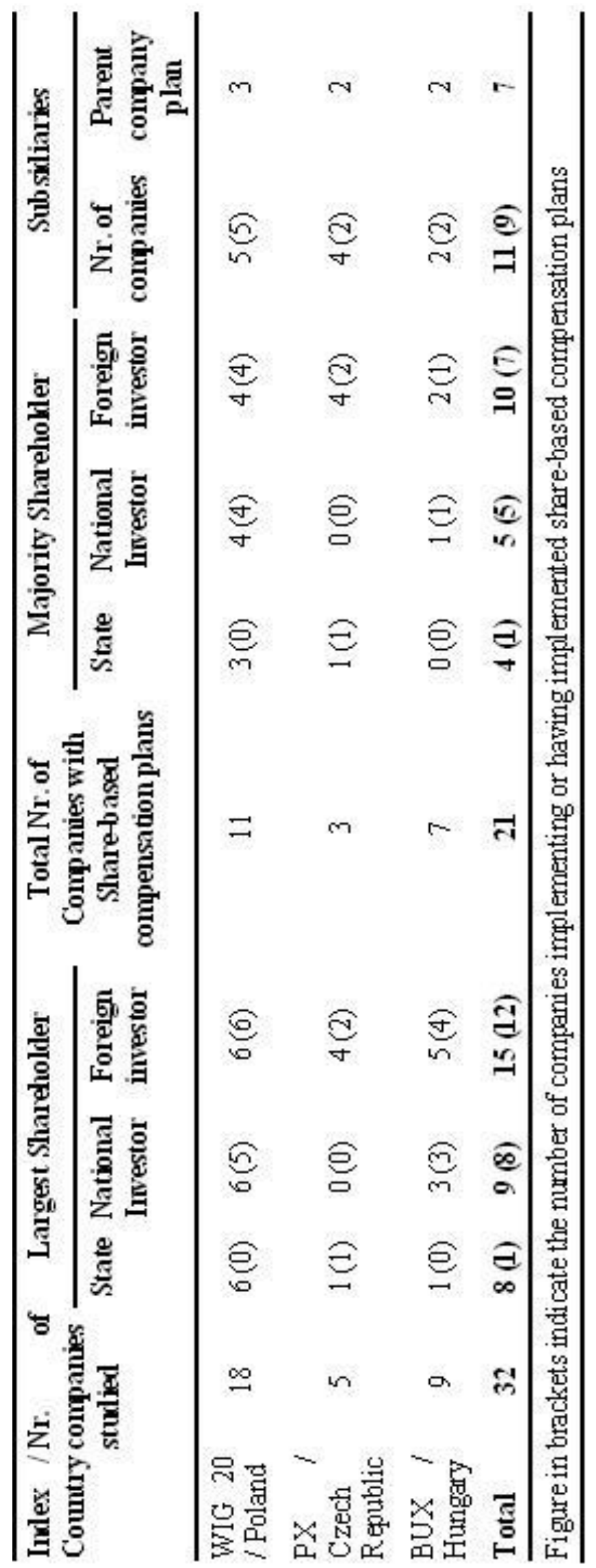


The necessity to modify parent company share-based schemes is caused mainly by legal limitations pertaining to certain compensation plans in the respective countries. For instance, according to the 2009 annual report of the German Deutsche Telekom, the ultimate parent of the Hungarian Magyar Telekom, "in 2001 and 2002, Deutsche Telekom also granted stock appreciation rights (SARs) to employees in countries where it was not legally possible to issue stock options" (Deutsche Telekom AG 2009:194), which included Hungary. However, even if corporations strive to standardise share-based compensation plans throughout their foreign operations by copying parent company compensation schemes, it is still often necessary to make at least minor adjustments to the local context. For example, the same Deutsche Telekom report reads: "The MTIP [Mid-Term Incentive Plan] of Magyar Telekom is based on the same terms and conditions as the MTIP described above [of Deutsche Telekom], except that the assessment benchmark is the performance of Magyar Telekom shares and the Dow Jones EURO STOXX ${ }^{\circledR}$ Total Return Index" (Deutsche Telekom AG 2009:197).

The analysis of the impact of the industry sector on share-based compensation practices showed the prevalence of such schemes in the financial sector. As presented in Table 4 below, share-based compensation plans are being or have been implemented by six of seven companies from the "credit intermediation and related activities" industry sub-sector, according to NAICS 2007 classification.

Here, the effect of state ownership on compensation plans in Poland is confirmed again: the only company from this industry sector not implementing or not having implemented such plans is a Polish bank with a significant share owned by the state. In two other industries, into which the largest number of companies fall, as well as in the total remaining industries, the spread of sharebased plans is much lower.

\section{Discussion}

The results of this study suggest a very strong effect of ownership structures on compensation practices in Poland, especially with respect to companies controlled or co-owned by the state. This could be attributed to any of the isomorphic forces described by DiMaggio and Powell (1991). While the impact of direct regulation on the adoption of share-based pay practices could certainly be defined as a coercive force, the behaviour of companies co-owned by the state, but which do not fall under the respective laws, could be attributed to both mimetic and normative mechanisms. 
Table 4. Share-based Compensation Plans in WIG 20, PX and BUX companies by NAICS 2007 industry sectors

\begin{tabular}{|c|c|c|c|c|c|c|c|c|}
\hline \multirow[t]{2}{*}{$\begin{array}{l}\text { Index I } \\
\text { Country }\end{array}$} & \multicolumn{2}{|c|}{$\begin{array}{c}\text { Credit } \\
\text { Intermediation and } \\
\text { Related Activities } \\
(522)\end{array}$} & \multicolumn{2}{|c|}{$\begin{array}{c}\text { Petroleum and } \\
\text { Coal Products } \\
\text { Manufacturing } \\
(324)\end{array}$} & \multicolumn{2}{|c|}{$\begin{array}{c}\text { Chemical } \\
\text { Manufacturing } \\
(325)\end{array}$} & \multicolumn{2}{|c|}{ Other sectors } \\
\hline & $\begin{array}{l}\text { Total } \\
\text { number of } \\
\text { companies }\end{array}$ & $\begin{array}{l}\text { Share- } \\
\text { based } \\
\text { comp. } \\
\text { plans }\end{array}$ & $\begin{array}{l}\text { Total } \\
\text { number of } \\
\text { companies }\end{array}$ & $\begin{array}{l}\text { Share- } \\
\text { based } \\
\text { comp. } \\
\text { Plans }\end{array}$ & $\begin{array}{l}\text { Total } \\
\text { number of } \\
\text { companies }\end{array}$ & $\begin{array}{l}\text { Share- } \\
\text { based } \\
\text { comp. } \\
\text { plans }\end{array}$ & $\begin{array}{l}\text { Total } \\
\text { number of } \\
\text { companies }\end{array}$ & $\begin{array}{l}\text { Share-based } \\
\text { comp. plans }\end{array}$ \\
\hline $\begin{array}{l}\text { WIG } 20 \\
\text { / Poland }\end{array}$ & 4 & 3 & 2 & 0 & 1 & 1 & 11 & 7 \\
\hline $\begin{array}{l}\text { PX / } \\
\text { Czech } \\
\text { Republi } \\
\text { c }\end{array}$ & 1 & 1 & 1 & 0 & 0 & 0 & 3 & 2 \\
\hline $\begin{array}{l}\text { BUX / } \\
\text { Hungary }\end{array}$ & 2 & 2 & 1 & 1 & 3 & 1 & 3 & 3 \\
\hline Total & 7 & 6 & 4 & 1 & 4 & 2 & 17 & 12 \\
\hline
\end{tabular}

Apart from Poland, however, it seems that state ownership of public company shares in the CEE region as a whole cannot be considered a constraint to the implementation of share-based schemes per se. The fact that the Czech company, which is controlled to a large extent by the state, implements such modern share-based incentives is probably a sign of less institutional constraints with respect to pay decisions on the one hand and more managerial autonomy on the other. This is consistent with evidence established in Western Europe. Several examples of Western public companies mainly owned by the local states show that the effect of state ownership on executive compensation in public companies in industrialised countries is not evident. Let us take the companies composing the German DAX stock market index, for instance. The German Deutsche Telekom AG, privatised in 1995, is still owned to a large extent by the state - almost $15 \%$ by the Federal Government and almost $17 \%$ by the stateowned (belonging both to the federal and federal state governments) KfW Bankengruppe (cf. http://www.telekom.com/dtag/cms/content/dt/de/22518). Nonetheless, the company previously ran a stock options plan, currently implements mid-/long-term cash incentive plans based on the development of the stock prices for its top management and the current CEO of the company, René Obermann, is one of the best-paid managers in Germany. On the other hand, the world leader in the electric utility market, the French EDF Group, with over $85 \%$ of the shares owned by the state (cf. http://shareholders-andinvestors.edf.com/edf-share/shareholding-structure-42691.html), does not offer share-based compensation elements to its top managers.

Based on our analysis of the companies from our sample we can also suggest that state shares in the Polish companies might also have an impact on share- 
based compensation plans in their CEE subsidiaries. Such an example is the Czech Unipetrol a.s., a subsidiary of Poland's PKN Orlen S.A. As of December 2009, the Polish State Treasury's share in PKN Orlen S.A. amounted to 27.52\%, and the company was thus not covered by the salary cap regulation. However, like the remaining corporations from the Polish sample, co-owned or controlled by the state, PKN Orlen S.A. did not provide any share-based compensation. As shown in Table 2, no share-based compensation was provided to the employees of its subsidiary, Unipetrol a.s., either. Given the fact that PKN Orlen S.A. strives to standardise its annual bonus system to cover key management employees in its group of companies, the absence of share-based compensation plans in its Czech subsidiary could also be seen as a part of the standardisation effort.

Thus, the very strong impact of state ownership in Polish public corporations, irrespective of the state share in them, and a lack of definitive evidence in other CEE country studies as well as elsewhere, enables us to come to a conclusion similar to the findings of Carroll and Ciscel (1982) in that executive compensation depends on the regulation density in which the companies are operating, in this case, on the regulation density with respect to executive pay. However, as we have not studied the absolute levels of compensation, it is the structure of pay which seems to be affected by the direct regulation of executive remuneration in state-controlled public companies, even if firms with state shares do not fall directly under such laws. It should also be noted that Poland is not only the only CEE state analysed in this paper that imposes the direct regulation of director's pay, but also a country with the strictest disclosure standards.

Another important issue is the transfer of parent company share-based compensation practices to subsidiaries. Our findings are similar to the results of studies on equity pay in US companies, e.g. Haynes (2008), who reports that according to a 2002 study performed by Towers Perrin, the overwhelming majority of US-American MNCs awarded their home-base stock option plans to non-US executives. Our sample, however, delivered two additionally important results. Firstly, the majority of MNCs analysed are European. Secondly, a transfer of broad-based share-based schemes has also been identified.

With respect to the impact of industry traits on the implementation of compensation practices, apart from the finance industry no obvious effect on the adoption of share-based compensation schemes could be identified. This is a result of the relatively low number of companies analysed, which is the most important limitation of this study. Another limitation of the results is that they do not deliver information on the amount of share-based compensation, which could serve as a basis for further analysis of the impact of industry sectors on executive pay. However, the absence of such schemes in many cases during the 
crisis, and still low disclosure standards in the region, did not allow such an analysis for the purpose of this study.

\section{Conclusion}

Based on our analysis of the annual reports of a sample of public companies composing three major national stock exchange indices in the Czech Republic, Hungary and Poland, we have demonstrated a strong impact of the regulatory environment on share-based compensation plans in the region. Notably, state shareholding has a major impact on the existence of such schemes in Polish publicly traded corporations, which could be considered as evidence of the rigid, direct regulation of executive pay in Poland in contrast to the Czech Republic and Hungary. Polish companies co-owned by the State Treasury, even in cases where they are not controlled by the state, have not introduced share-based compensation. A significant impact of foreign investors on the adoption of such schemes can be observed, primarily through the transfer of foreign parent company share-based plans to their subsidiaries. Although a high prevalence of share-based schemes has been identified among companies belonging to the finance industry, a further study of this impact based on a larger number of cases, and including data on compensation amounts, is required.

This study has both theoretical and practical implications. In both cases, the importance of legal environments across the globe is the focus of attention. With respect to academic research, we suggest that organisational theories should be applied in different national contexts under explicit consideration of specific institutional arrangements in respective countries. For instance, our study suggests that state shareholding in publicly traded companies per se seems to have a different impact on the implementation of organisational practices, depending on respective national regulations. This is in line with the assumption of Lan and Heracleous (2010) that the validity of the legal and agency theories of the firm are limited by the organisational and institutional environments.

The implications for practitioners are twofold. Firstly, it is necessary to consider differences in institutional arrangements, even between countries with seemingly similar developmental paths and political, cultural and economic links such as the Czech Republic, Poland and Hungary studied in this paper. Secondly, management decisions should be based on a holistic analysis of institutional, above all legal, environments, which are instrumental in ensuring location-based competitive advantage in the CEE region. 


\section{References}

Abrahamson, E. (1991): Managerial Fads and Fashions: The Diffusion and Refection of Innovations, in: Academy of Management Review, 16, 3, 586-612.

Bebchuk, L. A. (2010): How to Fix Bankers' Pay, in: Daedalus, 139, 4, 52-60.

Bertelsmann Stiftung (2010): Bertelsmann Transformation Index 2010: Poland Country Report, retrieved from: http://www.bertelsmann-transformationindex.de/bti/laendergutachten/laendergutachten/ostmittel-und-suedosteuropa/poland/ (accessed 4 January 2011).

Budhwar, P. S./Sparrow, P. R. (2002): An Integrative Framework for Understanding Crossnational Human Resource Management Practices, in: Human Resource Management Review, 12, 3, 377-403.

Carroll, T. M./Ciscel, D. H. (1982): The Effects of Regulations on Executive Compensation, in: Review of Economics \& Statistics, 64, 3, 505-09.

Cheffins, B. R./Thomas, R. S. (2002): Regulation and the Globalization (Americanization) of Executive Pay. Working Paper No. 02-05, Vanderbilt University Law School.

Chizema, A./Buck, T. (2006): Neo-institutional Theory and Institutional Change: Towards Empirical Tests on the Americanization of German Executive Pay, in: International Business Review, 15, 5, 488-504.

Chung, J. (2009): SEC Strengthens Pay Disclosure Rules, in: Financial Times, 16 December.

Craighead, J. A./Magnan, M. L./Thorne, L. (2004): The Impact of Mandated Disclosure on Performance-Based CEO Compensation, in: Contemporary Accounting Research, 21, 2, 369-98.

Deeg, R. (2005): Path Dependency, Institutional Complementarity, and Change in National Business Systems, in: Morgan, G./Whitley, R. (eds.): Changing capitalisms? Internationalization, Institutional Change, and Systems of Economic Organization, Oxford: Oxford University Press, 21-52.

Deutsche Telekom AG (2009): The 2009 Financial Year. Annual Report, retrieved from: http://www.download-

telekom.de/dt/StaticPage/82/04/80/deutsche_telekom_annual_report_2009_820480.pd f (accessed 11 October 2010).

DiMaggio, P. J./Powell, W. W. (1991): The Iron Cage Revisited: Institutional Isomorphism and Collective Rationality in Organizational Fields, in: Powell, W. W./DiMaggio, P. J. (eds.): The New Institutionalism in Organizational Analysis, Chicago: University of Chicago Press, 63-81.

Eisenhardt, K. M. (1989): Agency Theory: An Assessment and Review, in: Academy of Management Review, 14, 1, 57-74.

European Commission (2007): Report on the Application by Member States of the EU of the Commission Recommendation on Directors' Remuneration, retrieved from: http://ec.europa.eu/internal_market/company/docs/directorsremun/sec20071022_en.pdf (accessed 11 October 2010). 
Festing, M./Sahakiants, I. (2010): Compensation Practices in Central and Eastern European EU Member States-An Analytical Framework Based on Institutional Perspectives, Path Dependencies, and Efficiency Considerations, in: Thunderbird International Business Review, 52, 3, 203-16.

Florin, B./Hallock, K. F./Webber, D. (2010): Executive Pay and Firm Performance: Methodological Considerations and Future Directions, retrieved from: http://digitalcommons.ilr.cornell.edu/cri/15 (accessed 8 October 2010).

Haynes, K. T. (2008): Executive Compensation in an International Context. The Role of Informal and Formal Institutions, in: Gomez-Mejia, L./Werner, S. (eds.): Global Compensation. Foundations and perspectives, London and New York: Routledge, 192205.

Hofstede, G. (1980): Culture's Consequences: International Differences in Work-related Values. Beverly Hills, London: Sage Publications.

Jackson, T. (2011): Notions of Fair Executive Pay Rest with Public Opinion, in: Financial Times, 3 January.

Jensen, M. C./Meckling, W. H. (1976): Theory of The Firm: Managerial Behavior, Agency Costs and Ownership Structure, in: Journal of Financial Economics, 3, 4, 305-60.

Karoliny, Z./Farkas, F./Poór, J. (2009): In focus: Hungarian and Central Eastern European characteristics of human resource management - an international comparative survey, in: Journal for East European Management Studies, 14, 1, 9-47.

Köke, J./Schröder, M. (2003): The Prospects of Capital Markets in Central and Eastern Europe. Discussion Paper No. 02-57, Centre for European Economic Research.

Kostova, T./Roth, K. (2002): Adoption of an Organizational Practice by Subsidiaries of Multinational Corporations: Institutional and Relational Effects, in: Academy of Management Journal, 45, 1, 215-33.

Koubek, J. (2009): Managing Human Resources in the Czech Republic, in: Morley, M. J./Heraty, N./Michailova, S. (eds.): Managing Human Resources in Central and Eastern Europe, London: Routledge, 132-57.

Kurdelbusch, A. (2002): Multinationals and the Rise of Variable Pay in Germany, in: European Journal of Industrial Relations, 8, 3, 325-49.

Lan, L. L./Heracleous, L. (2010): Rethinking Agency Theory: The View from Law, in: Academy of Management Review, 35, 2, 294-314.

Martin, R. (2008): Post-socialist Segmented Capitalism: The Case of Hungary. Developing Business Systems Theory, in: Human Relations, 61, 1, 131-59.

Mercer (2007): Executive Compensation Disclosure in Europe, retrieved from: http://www.mercer.com/attachment.dyn?idContent=1282000\&idFile=396803 (accessed 15 September 2010).

Park, Y. W./Nelson, T./Huson, M. R. (2001): Executive Pay And The Disclosure Environment: Canadian Evidence, in: Journal of Financial Research, 24, 3, 347.

Pendleton, A./Blasi, J./Kruse, D./Poutsma, E./Sesil, J. (2002): Theoretical Study on Stock Options in Small and Medium Enterprises., retrieved from: http://ec.europa.eu/enterprise/policies/sme/files/support_measures/stock_options/theor etical_study_en.pdf (accessed 15 December 2010). 
Pennings, J. M. (1993): Executive Reward Systems: A Cross-National Comparison, in: Journal of Management Studies, 30, 2, 261-80.

Richardson, M. (2009): A Curb on Bank Bonuses Misses the Point, in: Financial Times, 8 October, 9.

Sharp, D. J./Salter, S. B. (1997): Project Escalation and Sunk Costs: A Test of the International Generalizability of Agency and Prospect Theories, in: Journal of International Business Studies, 28, 1, 101-21.

Von Glinow, M. A./Drost, E. A./Teagarden, M. B. (2002): Converging on IHRM Best Practices: Lessons Learned From a Globally Distributed Consortium on Theory and Practice 